\title{
The performance of surface and subsurface drainage on heavy clay soils in Yugoslavia
}

\author{
J. M. Groot
}

International Land Development Consultants (ILACO), Arnhem, the Netheriands

Accepted: 11 April 1974

\section{Summary}

Field drainage methods have been investigated on soils in the Sava River Basin, Yugoslavia, which have a well-permeable topsoil of about $0.3 \mathrm{~m}$ underlain by an impermeable subsoil. The systems tried are tube drainage at about $1.0 \mathrm{~m}$ depth, surface drainage with open field ditches and mole drainage.

Under rainfall horizontal flow through the topsoil takes place. The formulas for both the steady and non-steady state that apply to this flow have been presented. These formulas together with field observations about accessibility of the fields have rendered it possible to derive the drainage requirements for the climatological conditions and the soils as prevalent in the area.

In selecting the most suitable type of drainage system, the intended mechanization of agriculture has played a role. Partly because of this mechanization, subsurface drains are to be preferred; other factors in favour of subsurface drains are that they provide better drainage than surface drains, particularly during reclamation and the first years of cropping. In addition, subsurface drainage is expected to be more profitable than the other two systems although it requires a higher initial investment.

Under the soil conditions as prevailing in the area, flow over the surface is likely to occur. The factors determining the peak discharges of field drains have been discussed.

\section{Introduction}

In the Sava River Valley in northern Yugoslavia vast areas suffer from bad drainage conditions. Problems are worst along a $200 \mathrm{~km}$ stretch of the river between Zagreb and Nova Gradiska. In that area about 400000 ha need flood protection while for an additional 600000 ha insufficient drainage is the limiting factor for agricultural production.

At present flood protection measures are under way in this area. To study the possibilities of improved land use a 500-ha pilot farm was started $25 \mathrm{~km}$ east of Zagreb. It was established in 1969 by the Yugoslav government in cooperation with the Food and Agricultural Organization (FAO).

The aim of the project was to investigate suitable cropping patterns, mechanization and drainage for large agricultural production units of several thousands of hectares.

A map of the pilot farm is shown in Fig. 1. The area slopes from north to south with an average gradient of about $0.5 \%$. Annual floods occur to about the $98.0+\mathrm{m}$ contour line. To protect the pilot farm against these floods a dike was built around the area and pumping facilities were installed. 


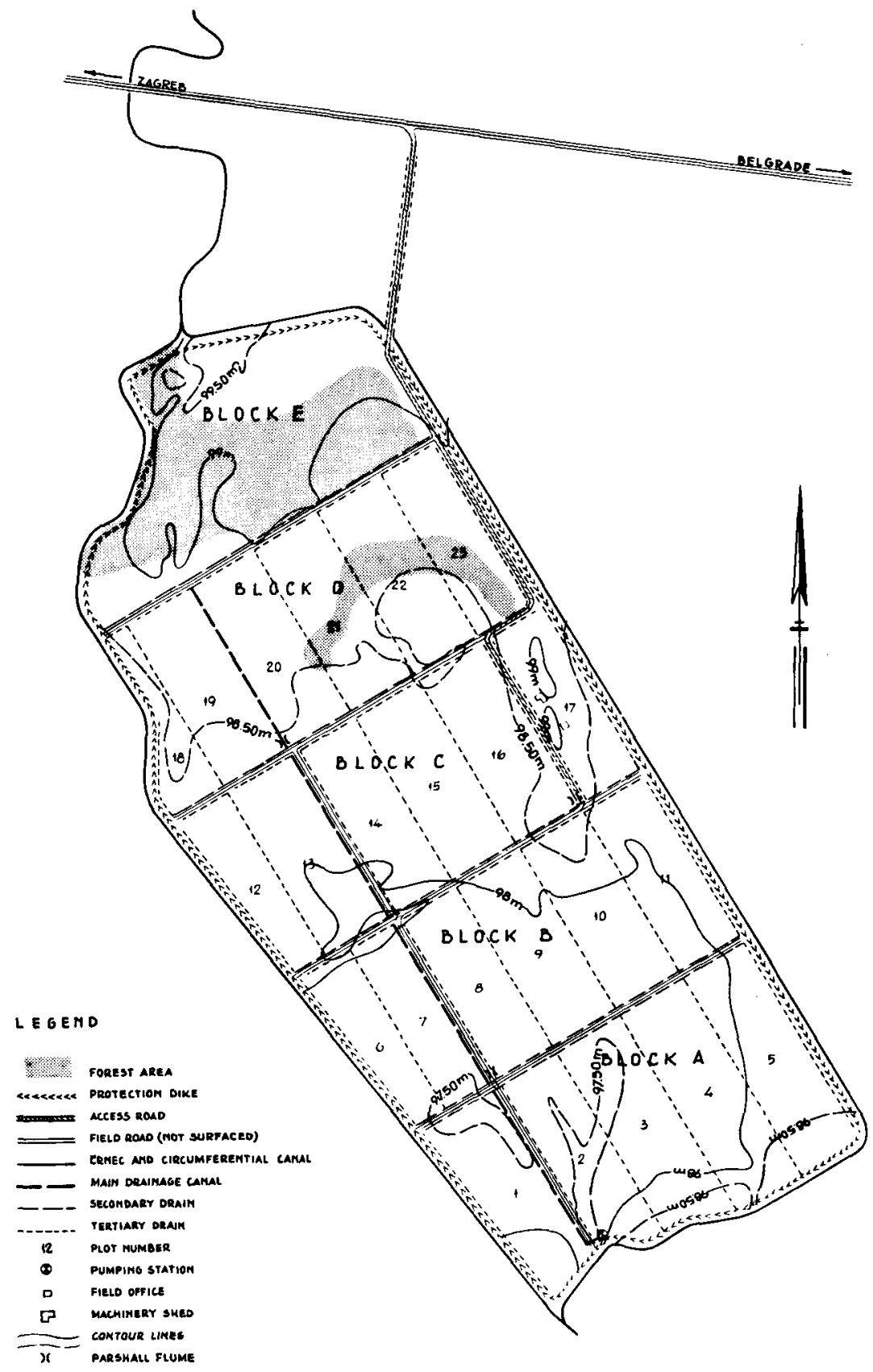

Fig. 1. Lay-out plan of the pilot farm (scale 1:32 000). 
Rectangular fields of about $300 \times 800 \mathrm{~m}$ were chosen as a basic unit in the layout with tertiary canals of $1.5 \mathrm{~m}$ deep in between. The area was divided into four blocks A-D, each block about 120 ha large and having a secondary drainage canal with a road alongside. Originally a fifth block $E$ was included but this was left out later because of heavy wood vegetation. Thus the northern boundary of the farm is formed by the road between blocks $\mathrm{D}$ and $\mathbf{E}$.

\section{Precipitation and evapotranspiration}

Daily precipitation figures were available from the station Rugvica, about $2 \mathrm{~km}$ west of the project (altitude $100 \mathrm{~m}, 45^{\circ} 45^{\prime} \mathrm{N} 16^{\circ} 14^{\prime} \mathrm{W}$ ). Records have been kept since 1924 . The average monthly totals and the yearly total are shown in Table 1.

The rainfall distribution is rather regular; two minor peaks occur in May-June and November. On the average the growing season (April-September) has more precipitation than the winter season (October-March). From December to February most precipitation falls as snow.

From the daily precipitation figures rainfall and drought duration curves were derived. An example for the months April-June is given in Fig. 2. During these months soil moisture conditions are the most critical with respect to field traffic, tillage and the air content of the soil. In winter the soil moisture content may be higher but the factors mentioned are less significant in that season. The letter F in Fig. 2 is the calculated frequency of each line.

Monthly potential evapotranspiration values of a short-cut grass surface $\left(E_{p}\right)$ were calculated with Penman's formula. The average values are given in Table 2.

Comparison of Tables 1 and 2 shows that, on the average, the precipitation is almost equal to the evapotranspiration in the months April-June. In the months July and August $E_{p}$ exceeds $P$ by about $50 \mathrm{~mm}$, but in September there is already a precipitation surplus.

Table 1. Average monthly and yearly precipitation (P) (mm) at Rugvica.

\begin{tabular}{lllllllllllll}
\hline Jan. & Feb. & Mar. & Apr. & May & June & July & Aug. & Sep. & Oct. & Nov. & Dec. & Total \\
59 & 52 & 48 & 67 & 92 & 100 & 86 & 76 & 82 & 68 & 104 & 78 & 912 \\
\hline
\end{tabular}

Table 2. Average monthly evatranspiration $\left(E_{p}\right)$ values $(\mathrm{mm})$.

\begin{tabular}{lllllll}
\hline Apr. & May & June & July & Aug. & Sep. & Total Apr.-Sep. \\
63 & 93 & 108 & 115 & 96 & 54 & 529 \\
\hline
\end{tabular}

\section{Permeability of the soil profile}

The drainage investigations were carried out on basin clay soils of which two types were distinguished, viz low basin soils and high basin soils. The boundary between the two soil types coincides roughly with the $98.0+\mathrm{m}$ contour line in Fig. 1. Measure- 
SURFACE AND SUBSURFACE DRAINAGE ON HEAVY CLAY SOILS

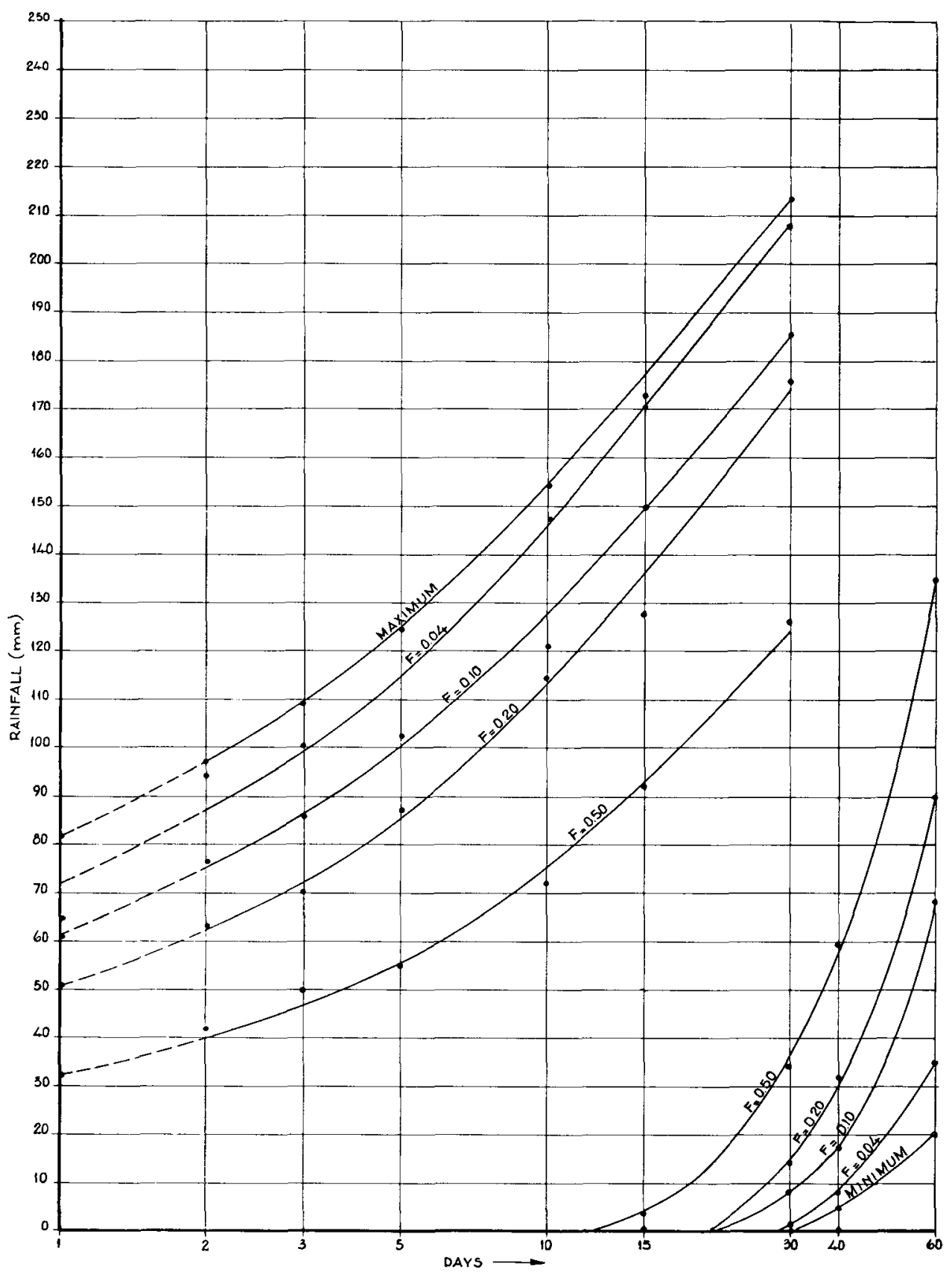

Fig. 2. Rainfall and drought duration lines for the months April-June (Rugvica, 1924-1968). 
ments were done on ten fields (about 240 ha), about equally divided over low and high basin soils.

The soil profile of the basin soils consists of the following layers:

- A topsoil with a depth $\mathrm{D}_{1}$ of $0.2-0.3 \mathrm{~m}$, containing $50-65 \%$ clay $(<2 \mu \mathrm{m})$. The humus content varies from about $5 \%$ on the high basin soils to about $10 \%$ on the low basin soils. The permeability $\mathrm{k}_{1}$ of this layer depends on several conditions. Before reclamation permeabilities were measured of $0.005-0.3 \mathrm{~m} / 24 \mathrm{~h}$. After reclamation measurements indicated values of $1-3 \mathrm{~m} / 24 \mathrm{~h}$. According to criteria developed by Boekel (1959) the structure of the topsoil is easily damaged by mechanical influences (field traffic, tillage). Damage of the soil structure will result into a decrease of the permeability in the topsoil.

- A second layer with thickness $D_{2}$ extending from $0.2 / 0.3 \mathrm{~m}$ to $0.7 / 1.3 \mathrm{~m}$ below the surface, with an equally high percentage of clay. The permeability $\mathrm{k}_{2}$ is about $2 \mathrm{~mm} / 24$ h. The material of this layer shrinks and swells considerably, which is ascribed to the presence of montmorillonite. No quantitative data are available on this matter.

- A third layer consisting of lighter sediment with a permeability $\mathrm{k}_{3}$ of $0.2-1.0 \mathrm{~m} / 24 \mathrm{~h}$ on the low basin soils and 1.0-5.0 m/24 h on the high basin soils. The depth of this layer is limited. At about $2.0 \mathrm{~m}$ below the surface heavier layers occur, which limit the groundwater flow considerably.

The permeability was determined by different methods:

- By percolation of small undisturbed samples of $100 \mathrm{~cm}^{3}$ in the laboratory. This method was applied to the topsoil and second layer before reclamation. The impression was gained that smearing of the surfaces of the samples greatly influenced the measurements, so the method was abandoned during later investigations.

By infiltration measurements in infiltrometers with a diameter of about $0.3 \mathrm{~m}$ installed in the field. This method was applied to the topsoil and the second layer after reclamation. The measurements were carried out during early spring to prevent that low moisture content and cracking of the soil would be of influence. Each measurement was continued for 2-3 days.

Infiltration measurements in the topsoil were carried out at 23 locations. The infiltration rates are influenced by the low permeability of the second layer. The water that percolates through the infiltrometer flows sideways until the infiltration into the second layer (rate $\times$ surface) equals the infiltration through the infiltrometer. In order to be able to calculate an approximate permeability of the topsoil, water potentials were measured immediately outside the infiltrometer ring by shallow piezometers in the topsoil.

To prevent considerable potential losses by flow underneath the ring, the lower rim of the infiltrometer was consistently kept about $0.1 \mathrm{~m}$ above the boundary between the topsoil and the second layer. The permeabilities calculated from the measurements amounted to $1-3 \mathrm{~m} / 24 \mathrm{~h}$.

Infiltration rates of the second layer were measured at 10 locations at depths of $0.25,0.50$ and $0.75 \mathrm{~m}$ below the surface. Most measurements showed rates between 0.0 and $1.0 \mathrm{~cm} / 24 \mathrm{~h}$.

- The auger hole method was used to measure the permeabilities of the third layer.

- After some fields had been provided with subsurface drains (1.0-1.2 $\mathrm{m}$ deep), measurements were carried out to determine the water potentials in the soil and the discharges of the drains. From these data soil permeabilities could be calculated, which generally confirmed the values obtained in previous measurements. In addition, the values of the storage coefficients $\mu_{1}$ and $\mu_{2}$ of the first and the second layer were 
calculated by applying non-steady state relations. The value of $\mu_{1}$ was about $10 \%$, that of $\mu_{2}$ about $1.5 \%$.

\section{Measurements on drainage systems}

The following drainage systems were investigated:

- Subsurface drains at a depth of 1.0-1.2 m at distances varying from 12.5 to $62.5 \mathrm{~m}$. - Surface drains, consisting of open field ditches at distances varying from 25 to $90 \mathrm{~m}$. - Subsurface drains at a depth of $1.0-1.2 \mathrm{~m}$ and at distances of $45 \mathrm{~m}$. The trenches were filled with gravel and mole drainage was applied crosswise to the drains at distances of $5 \mathrm{~m}$ and at a depth of about $0.6 \mathrm{~m}$.

All systems were tried on a practical scale, so their performance could be judged under normal conditions of reclamation and cultivation.

In spring, when the soil moisture content is high, almost any amount of rainfall results into saturation of part of the topsoil. In that case the drainage flow consists of two components:

- Shallow flow $q_{1}$, which is the horizontal flow through the topsoil to the drains. In the case of subsurface drains the water enters the drain via the trench.

- Deep flow $\mathrm{q}_{2}$, through the second and the third layer into the drains. This flow only takes place in the case of subsurface drains.

\section{Shallow flow}

Shallow flow can be considered a drainage flow with the drains located on the impermeable layer. A formula for the steady state is:

$$
\mathrm{q}_{1}=4 \mathrm{k}_{1} \mathrm{~h}_{1}^{2} / \mathrm{L}^{2}
$$

in which $h_{1}=$ the water potential in the topsoil in the centre between two drains; $\mathbf{L}=$ drain distance.

This formula was given by Hooghoudt (1937); the derivation implies that the shape of the water-table is an ellipse. A different kind of steady state equation was worked out by Fukuda (1957). He assumes that the water-table in the topsoil is horizontal, and arrives at the following relation between $q_{1}$ and $h_{1}$ :

$$
\mathrm{q}_{1}=1.5 \cdot \mathrm{k}_{1} \mathrm{~h}_{1} / \mathrm{L}
$$

For the same value of $h_{1}$ the difference in discharge between the Hooghoudt and Fukuda formulas is considerable.

The shallow flow measurements done on the project showed that Fukuda's formula explained the data better than Hooghoudt's for the following reasons:

-- the relation between $q_{1}$ and $h_{1}$ appeared to be linear;

- the $k_{1}$ values calculated from the observed values of $q_{1}$ and $h_{1}$ with Eq. 2 agreed to those measured in the infiltrometers;

-. the shape of the water-table in the topsoil was horizontal rather than elliptic.

An example is given in Fig. 3; the upper part shows the shape of the water-table at discharge rates of $17.2,10.0$ and $4.8 \mathrm{~mm} / 24 \mathrm{~h}$ and the lower part the relation between $q$ and $h_{1}$. The quantity $q$ is the total drain outflow including the deep flow $q_{2}$. As will be discussed later, $\mathrm{q}_{2}$ can be considered to be constant; it has a value of about $2 \mathrm{~mm} / 24 \mathrm{~h}$ in Fig. 3.

Accepting Eq. 2 for the shallow flow a non-steady state equation was derived by 

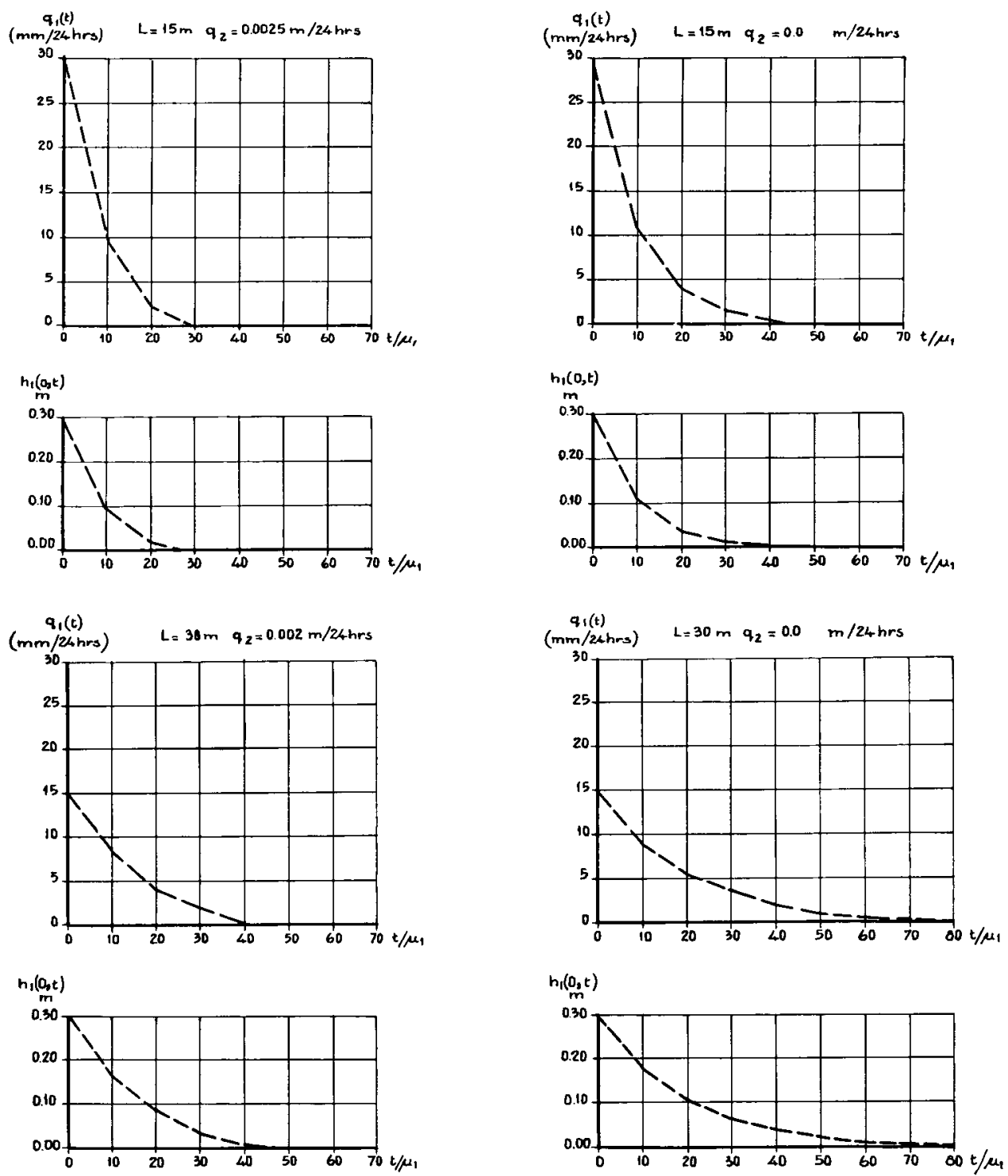

Fig. 3. The shape of the water-table in the top soil during shallow flow and the relation between $q$ and $h_{1}$ for the same case (measurements carried out on plot 19, drains 49 and 50 ).

applying a similar procedure as used by de Zeeuw \& Hellinga (1958). Non-steady flow was considered to be a sequence of steady states during short time intervals dt. During such an interval, the difference between the precipitation $P$ and the discharge $q(t)$ is equal to the change in water level times the storage coefficient $\mu_{1}$. Assuming a horizontal water-table, as is the case with Eq. 2, one arrives at the following formula: 


$$
\mathrm{q}_{1}(\mathrm{t})+\mathrm{q}_{2}-\mathrm{P}=-\mu_{1} \cdot \mathrm{dh}_{1}(0, \mathrm{t}) / \mathrm{dt}
$$

in which $\mathrm{q}_{1}(\mathrm{t})=$ the shallow flow at time $\mathrm{t} ; \mathrm{q}_{2}=$ the deep flow, which is a constant; $\mathrm{P}=$ a constant precipitation rate; $\mu_{1}=$ the storage coefficient of the topsoil; $h_{1}(0, t)=$ the height of the saturated zone in the topsoil in the middle between two drains at time $t$.

Substituting $h_{1}(0, t)$ by $q_{1}(t)$ according to Eq. 2 one obtains the following equation after integration:

$$
\frac{\mathrm{q}_{1}(\mathrm{t})+\mathrm{q}_{2}-\mathrm{P}}{\mathrm{q}_{1}(0)+\mathrm{q}_{2}-\mathrm{P}}=\exp \left(-\frac{1.5}{\mathrm{~L}} \cdot \frac{\mathrm{k}_{1}}{\mu_{1}}\right)
$$

Eq. 4 can also be expressed in terms of $h_{1}(0, t)$ by substituting $q_{1}(t)$ by $h_{1}(0, t)$ according to Eq. 2. This gives the following equation:

$$
\frac{\mathrm{h}_{1}(0, \mathrm{t})+\left(\mathrm{q}_{2}-\mathrm{P}\right) \cdot\left(\mathrm{L} / 1 \cdot 5 \cdot \mathrm{k}_{1}\right)}{\mathrm{h}_{1}(0,0)+\left(\mathrm{q}_{2}-\mathrm{P}\right) \cdot\left(\mathrm{L} / 1 \cdot 5 \cdot \mathrm{k}_{1}\right)}=\exp \left(-\frac{1.5 \cdot \mathrm{k}_{1}}{\mathrm{~L}} \cdot \frac{\mathrm{t}}{\mu_{1}}\right)
$$

Deep flow

Deep flow can be described by the steady state formulas of Hooghoudt (1940) and Ernst (1963). A discussion of these formulas in English is given by van Beers (1965). The application of the formulas to basin soils in the Netherlands was discussed by van Hoorn (1960).

By measuring drain discharges and potential heads in the topsoil and the third layer, the total drain discharge can be separated into its deep and shallow components. In addition, values of $\mathbf{k}_{2}$ and $\mathbf{k}_{3} \mathrm{D}_{3}$ can be calculated.

The magnitude of deep flow depends upon the potential head $h_{3}$ in the third layer and the permeability $k_{2}$ of the second layer.

If $h_{3}$ is small (about $0.25 \mathrm{~m}$ or smaller), deep flow can be considered to be equal to $\mathrm{k}_{2}$. As a result deep flow remains almost constant for several days after rainfall. For the large $\mathrm{k}_{3} \mathrm{D}_{3}$ values of the high basin soils, this is the case with fairly wide drain spacings of $40 \mathrm{~m}$ or more. On the low basin soils with smaller $\mathrm{k}_{3} \mathrm{D}_{3}$ values the drain spacings have to be narrower in order to let $\mathrm{q}_{2}$ equal $\mathrm{k}_{2}$.

If $h_{3}$ is large and extends considerably into the second layer, deep flow is smaller than $\mathrm{k}_{2}$. With $\mathrm{k}_{2}$ about equal to $2 \mathrm{~mm} / 24 \mathrm{~h}$, deep flow soon becomes negligible. This situation occurs in two cases:

- When the drain distance is large or when the $\mathrm{k}_{\mathbf{3}} \cdot \mathrm{D}_{\mathbf{3}}$ value is small, or both.

- When the second layer extends below the drains. Even if the drains are only $0.1 \mathrm{~m}$ above the lower boundary of the second layer, deep flow is already reduced considerably.

\section{Performance of the drainage systems}

Under the given conditions it is inevitable that after rain of any importance part of the topsoil becomes saturated. Therefore, drainage design should primarily aim at evacuating excess water from the topsoil as soon as possible. The time required to have the water level in the topsoil reduced from an initial value $h_{1}(0,0)$ to zero can be calculated with Eq. 5. The results of such calculations are shown in Fig. 4.

In the figure it is assumed that at $t=0$ the value of $h_{1}(0,0)$ was equal to $D_{1}$ $(0.30 \mathrm{~m})$. So the topsoil is wholly saturated; the precipitation rate $\mathrm{P}$ is assumed to be 

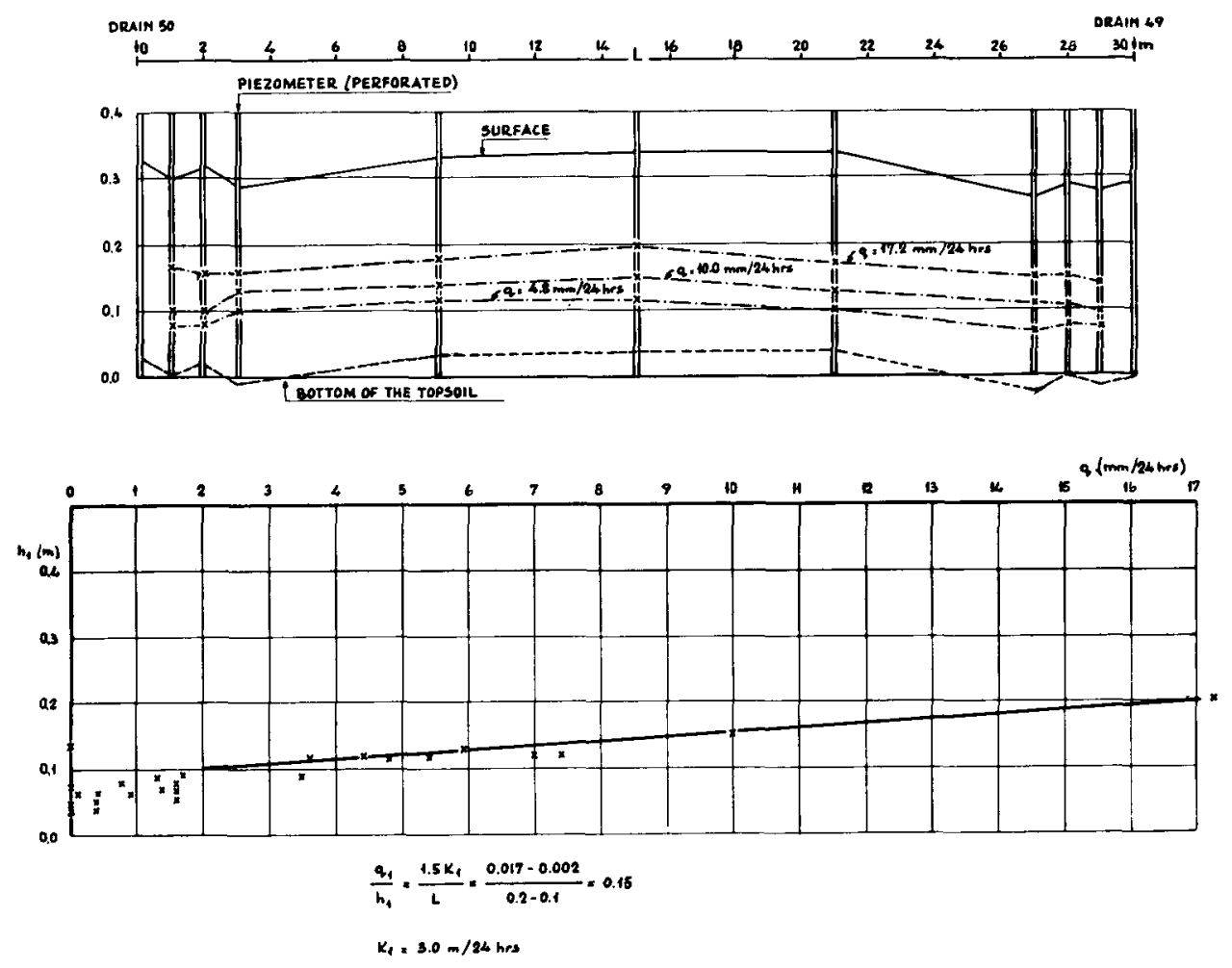

Fig. 4. The decrease of $h_{1}(0, t)$ and $q_{1}(t)$ with $t / \mu_{1}$ for $L=15 \mathrm{~m}\left(q_{2}=0.0025\right.$ and $\left.0.0 \mathrm{~m} / 24 \mathrm{~h}\right)$ and $\mathrm{L}=30 \mathrm{~m}\left(\mathrm{q}_{2}=0.002\right.$ and $\left.0.0 \mathrm{~m} / 24 \mathrm{~h}\right)$.

zero. The values of $\mathrm{k}_{1}$ and $\mu_{1}$ are taken at $1.0 \mathrm{~m} / 24 \mathrm{~h}$ and $10 \%$, respectively. The decrease of $h_{1}(0, t)$ and $q_{1}(t)$ is set out against $t / \mu_{1}$. With $\mu_{1}$ equal to $10 \%$, ten units of $t / \mu_{1}$ are equal to one day.

The calculations were made for drain distances of 15 and $30 \mathrm{~m}$ under two conditions, viz with and without deep flow. With the larger drain distance deep flow is assumed to be smaller than with the narrower one. Generally speaking, the effect of drain distance on the magnitude of deep flow is small.

The values of $\mathrm{q}_{1}(\mathrm{t})$ on the vertical axis represent the shallow flow only, so in order to arrive at the total drain outflow $\mathrm{q}(\mathrm{t})$ the values of the deep flow $\mathrm{q}_{2}$ have to be added.

Fig. 4 shows that doubling the drain distance also about doubles the time to reduce $h_{1}(0, t)$ to zero. The influence of the deep flow is less pronounced than that of the drain distance. The interesting fact about Fig. 4 is that the calculated values of $t / \mu_{1}$ at which $h_{1}(0, t)$ becomes zero, about agreed to the waiting time before the fields became accessible after major rain. For drain distances of about $15 \mathrm{~m}$ this time was about 3 days, for larger distances it increased considerably, so that land preparation on these fields was frequently delayed.

As in many cases a deep flow of $2 \mathrm{~mm} / 24 \mathrm{~h}$ can not be attained there seems to be little reason to prefer subsurface drainage to surface drainage. The experience gained 
on the pilot farm, however, was much in favour of subsurface drainage for the following reasons:

- As Fig. 4 shows, a drain distance of about $15 \mathrm{~m}$ is necessary to provide satisfactory conditions for mechanized agriculture. Open surface drains at these distances conflict with mechanization. Mechanization of agricultural operations requires the surface drains to be spaced at at least $25 \mathrm{~m}$, which does not provide adequate drainage.

- A subsurface system can be installed before reclamation, as soon as the fields have been cleared of heavy vegetation. The topography of the surface is generally flat enough to install subsurface drains with a drainage machine prior to land levelling. Thus all reclamation activities can be done on well drained fields.

The construction of open surface drains was done with rotary ditchers. They put higher requirement to the topography of the surface than the drainage machine and land levelling is necessary before surface drains are constructed. This implies that the first ploughing and subsequent discing has to take place under undrained conditions. This caused that reclamation of fields with surface drains was often delayed on the pilot farm, on some fields even by a year.

- After reclamation the fields with surface drains posed considerably more difficulties to cultivation than the fields with subsurface drains. This was not only a matter of drain distance. It appeared to be impossible to have well-functioning surface drains constructed on these heavy soils within one year. Surface systems require considerable reshaping during the first 2-3 years, after which the normal maintenance is a yearly affair.

The mole drainage system has similar disadvantages. The subsurface drains can be installed at an early stage of reclamation, but because their spacing is $45 \mathrm{~m}$, the system provides limited drainage. On the other hand the transport of gravel to fill the trenches makes heavy demands on the accessibility of the fie!d. The moles can be put in only after land levelling.

The mole drains are placed in the second layer; because of the low permeability of this layer they draw little water through their walls. Most water reaches the mole from the surface through the slit that is made by the knife of the mole plough. This makes the system vulnerable. The first experience indicated that at least during the first few years moling has to be renewed annually.

Under the given soil conditions, subsurface drains have the disadvantage that the permeability of the drain trench should be high. If the drains are $15 \mathrm{~m}$ apart and if the trench width is $0.25 \mathrm{~m}$, a discharge of $20 \mathrm{~mm} / 24 \mathrm{~h}$ requires a permeability in the trench of $1.2 \mathrm{~m} / 24 \mathrm{~h}$. Piezometers placed in the trenches and peak discharges measured showed that such permeabilities and even larger values occured. Only continued measurements can show whether they remain. If not, gravel will have to be put into the trenches, which will almost double the costs of the drainage system.

\section{Comparison of costs and yields}

Construction and maintenance costs were calculated and converted into annual costs. It appeared that surface drainage with drains $25 \mathrm{~m}$ apart is the least expensive. The difference in costs between this system and a subsurface drainage system with drains $15 \mathrm{~m}$ apart was such, however, that a yield increase of about $300 \mathrm{~kg}$ wheat/ha could pay for the difference. The first yield determinations indicated that such an increase or an even larger one is attainable with subsurface drainage.

The mole drainage system, with an annual renewal of the moles, is the most 
expensive. Its performance was satisfactory and comparable to that of the subsurface drainage system.

The crops were mainly wheat and maize in the initial stage of the project. Because of the prevailing conditions of soil and climate, however, agriculture will have to be directed to the production of fodder crops in the future. All three drainage systems, subsurface drainage at $15 \mathrm{~m}$, surface drainage at $25 \mathrm{~m}$ and the combination of mole drainage and subsurface drainage will then have to be revaluated.

\section{Occurrence of surface flow}

Under heavy rain the topsoil becomes saturated, and when the rain still continues, flow over the surface takes place. To determine at what rain frequencies this happens, Eq. 5 was used to calculate the rise of the water table in the topsoil under a constant rainfall intensity P. It was assumed that deep flow was negligible, that the second layer was saturated, and that the moisture conditions in the topsoil were such that the percentage of air-filled pores was equal to $\mu_{1}$. The value for $\mu_{1}$ was again taken at $10 \%$ and that for $\mathrm{k}_{1}$ at $1.0 \mathrm{~m} / 24 \mathrm{~h}$.

Surface flow starts when $h_{1}(0, t)$ is equal to $D_{1}$, for which a value of $0.3 \mathrm{~m}$ was taken. By using in Eq. 5 the value 0.0 for $h_{1}(0,0)$ and the value 0.3 for $h_{1}(0, t)$, one obtains the following relations between $P$ and $t$ :

$$
\begin{aligned}
& \text { for } L=15 \mathrm{~m}: P=0.03 /(1-\exp .(-\mathrm{t})) \\
& \text { for } \mathrm{L}=30 \mathrm{~m}: \mathrm{P}=0.015 /(1-\exp .(-0.5 \mathrm{t}))
\end{aligned}
$$

Assuming that the values of $t$ range from one hour to 5 days, one obtains the $P$ values as given in Table 3. As $P$ is the rainfall intensity, the values of P.t being the total rainfall amounts were also calculated.

Comparison of the rainfall amounts of Table 3 with those given in Fig. 2 indicates that for values of $t$ up to 1 day, the frequency with which surface flow occurs is rather high. Thus peak discharges occurring with a frequency $F$ of 0.2 or less will certainly be composed of surface flow together with shallow flow.

Furthermore, the differences between the two drain distances are rather small. For values of $t$ smaller than one day surface flow occurs at both distances when the precipitation exceeds values of $30-40 \mathrm{~mm}$. It is also of little importance whether this amount falls within one hour or within 12 hours. This is understandable because the outflow of the drains is small during short periods. The water tables in the topsoil

Table 3. Values of $\mathbf{P}$ and $\mathbf{L}$ at which surface flow starts.

\begin{tabular}{llllll}
\hline t (days) & $\mathrm{L}=15 \mathrm{~m}$ & & $\mathrm{~L}=30 \mathrm{~m}$ \\
\cline { 2 - 3 } \cline { 5 - 6 } \cline { 5 - 6 } & $\mathrm{P}(\mathrm{mm} / 24 \mathrm{~h})$ & P.t $(\mathrm{mm})$ & & $\mathrm{P}(\mathrm{mm} / 24 \mathrm{~h})$ & P.t $(\mathrm{mm})$ \\
$0.042^{*}$ & 732 & 31 & & 715 & 30 \\
0.5 & 76 & 38 & & 68 & 34 \\
1 & 48 & 98 & & 38 & 38 \\
3 & 32 & 150 & & 16 & 57 \\
5 & 30 & & & &
\end{tabular}


are, therefore, primarily governed by the rainfall amounts. During longer periods of time the differences in drain discharge between the two drain spacings become more important.

\section{Peak discharges}

Eq. 4 and 5 can be used to predict daily peak discharges under surface flow. This will be discussed for a fictitious rain based on the data of Fig. 2. According to this figure the lower part of the line with $F=0.04$ can be considered to consist of the following rainy period of five days:

$$
\begin{aligned}
& \text { day } 1, \mathbf{P}=7 \mathrm{~mm} \\
& \text { day } 2, \mathbf{P}=8 \mathrm{~mm} \\
& \text { day } 3, \mathbf{P}=10 \mathrm{~mm} \\
& \text { day } 4, \mathbf{P}=15 \mathrm{~mm} \\
& \text { day } 5, \mathbf{P}=75 \mathrm{~mm}
\end{aligned}
$$

The smaller rainfall amounts have been assumed to occur before the larger ones because this leads to a more critical situation. With the equations mentioned, $h_{1}(0, t)$ and $q_{1}(t)$ can be calculated for any value of $t$. This was done in Table 4 for a drain distance of $15 \mathrm{~m}$.

The same conditions as in Table 3 being applied $\left(h_{1}(0,0)=0.0 \mathrm{~m} ; \mathrm{q}_{2}=0.0 \mathrm{~mm} /\right.$ $24 \mathrm{~h}$ ), the percentage of air filled pores in the topsoil is equal to $\mu_{1}$, and the second

Table 4. Calculation of the expected discharge rates in spring, for a rainy period with frequency $F=0.04$.

\begin{tabular}{llllcl}
\hline $\begin{array}{l}\mathrm{t} \\
(\text { days })\end{array}$ & $\begin{array}{l}\mathrm{P} \\
(\mathrm{mm})\end{array}$ & $\begin{array}{l}\mathrm{h}_{1}(0, \mathrm{t}) \\
(\mathrm{m})\end{array}$ & $\begin{array}{l}\mathrm{q}_{1}(\mathrm{t}) \\
(\mathrm{mm} / 24 \mathrm{~h})\end{array}$ & $\begin{array}{l}\text { Amount of } \\
\text { discharge } \\
\text { by shallow } \\
\text { flow } \\
(\mathrm{mm})\end{array}$ & $\begin{array}{l}\text { Amount of } \\
\text { discharge } \\
\text { by surface } \\
\text { flow } \\
(\mathrm{mm})\end{array}$ \\
0 & 7 & 0.0 & 0 & 2.0 & \\
1 & 8 & 0.04 & 4 & 5.5 & \\
2 & 8 & 0.07 & 7 & 8.0 & \\
3 & 10 & 0.09 & 9 & 11.0 & \\
4 & 15 & 0.13 & 13 & 6.5 & \\
4.3 & 22 & 0.30 & 30 & 21.0 & 32.0 \\
5.0 & 53 & 0.30 & 30 & 7.8 & \\
5.3 & 0 & 0.22 & 22 & 15.0 & \\
6.3 & 0 & 0.08 & 8 & 5.5 & \\
7.3 & 0 & 0.03 & 3 & & \\
\hline
\end{tabular}


layer is fully saturated. Values of $k_{1}$ and $\mu_{1}$ were again taken at $1.0 \mathrm{~mm} / 24 \mathrm{~h}$ and $10 \%$.

Table 4 gives values of $t$ and $P$ in the first and second column. The third and fourth column present values of $h_{1}(0, t)$ and $q_{1}(t)$. The fifth column gives the discharge by shallow flow between successive values of $t$.

At the end of the fourth day $h_{1}(0,4)$ is equal to $0.13 \mathrm{~m}$. The $75 \mathrm{~mm}$ rain on the following day fills the topsoil to the surface and surface flow takes place. The moment $t$ at which surface flow starts can be calculated. With $P=75 \mathrm{~mm} / 24 \mathrm{~h}, \mathrm{~h}_{1}(0,4)=$ $0.13 \mathrm{~m}$ and $h_{1}(0, t)=0.30 \mathrm{~m}$, Eq. 4 and 5 give a value of 4.3 for $\mathrm{t}$. Between $\mathrm{t}=4.0$ and $\mathrm{t}=4.3$ the amount of rain is $0.3 \times 75=22 \mathrm{~mm}$; the discharge during the same period is $6.5 \mathrm{~mm}$ and consists of shallow flow.

The topsoil remains saturated as long as the rain continues, i.e. until $t=5.0$. Between $\mathrm{t}=4.3$ and $\mathrm{t}=5.0$ the precipitation is $0.7 \times 75=53 \mathrm{~mm}$; the discharge rate of shallow flow remains constant, namely $30 \mathrm{~mm} / 24 \mathrm{~h}$. Hence between $\mathrm{t}=4.3$ and $t=5.0$ the total amount of shallow flow is $0.7 \times 30=21 \mathrm{~mm}$.

The difference between precipitation and shallow flow between $t=4.3$ and $t=5.0$ is $32 \mathrm{~mm}$. This amount is supposed to run off as surface flow. If the surface flow ends within 24 hours after starting, i.e. before $t=5.3$, the largest discharge occurs between $\mathrm{t}=4.3$ and $\mathrm{t}=5.3$, being a total of $21.0+7.8=28.8 \mathrm{~mm}$ by shallow flow and $32 \mathrm{~mm}$ by surface flow. The average discharge rate is $28.8+32 \sim 61 \mathrm{~mm} / 24 \mathrm{~h}$. After $\mathrm{t}=5.0$ precipitation stops and $\mathrm{h}_{1}(0, \mathrm{t})$ and $\mathrm{q}_{1}(\mathrm{t})$ decrease in the same way as in Fig. 4 .

The discharge rate of $61 \mathrm{~mm} / 24 \mathrm{~h}$ occurs at the drain outlets. It can be used to calculate a required pumping capacity if the following conditions are met:

- The area should be small enough to validate the assumption that the rainfall distribution is equal over the whole area. For the pilot farm of 500 ha this assumption seems to be justified.

- The travelling time of the water from the most remote drain outlet to the pumping station should be small. On the pilot farm the largest distance of travelling through the canals is about $4 \mathrm{~km}$. With an average flow velocity in the canals of $0.3 \mathrm{~m} / \mathrm{s}$ the maximum travelling time is $3-4$ hours.

Thus the water discharged by drains arrives at the pumping station relatively rapidly. As the capacity of the pumping station is expressed in millimetres per 24 hours, there is little objection against using drain discharges to calculate the required pumping capacity.

The required pumping capacity is influenced by the storage capacity of the canal system. If the run-off rates of the area exceed the pumping capacity, water accumulates in the lower canal system in front of the station. The slope of the area is such that the lower-lying canals may fill up to their borders, while the higher-lying canals remain almost empty. When the lower canals fill up, their flow velocities become almost zero and the water level may be considered to be horizontal.

Therefore, the canal storage was considered to be the content of the canal system between two horizontal planes, one at the level at which pumping is supposed to start (the lowest pumping level) and one at the level at which flooding of the lower-lying lands begins. The difference between the two levels is about $1.5 \mathrm{~m}$; the storage in the canal system between these two levels was calculated to be $15 \mathrm{~mm}$.

With the discharge rate of $61 \mathrm{~mm} / 24 \mathrm{~h}$ calculated in Table 4 , the pumping capacity should be $61-15=46 \mathrm{~mm}$ if flooding should not last longer than 24 hours. If flooding is allowed to last 48 hours at most, the pumping capacity can be equal to $(61+15-$ 15) $/ 2 \sim 30 \mathrm{~mm} / 24 \mathrm{~h}$, the discharge rate of the drains being $15 \mathrm{~mm} / 24 \mathrm{~h}$ between 


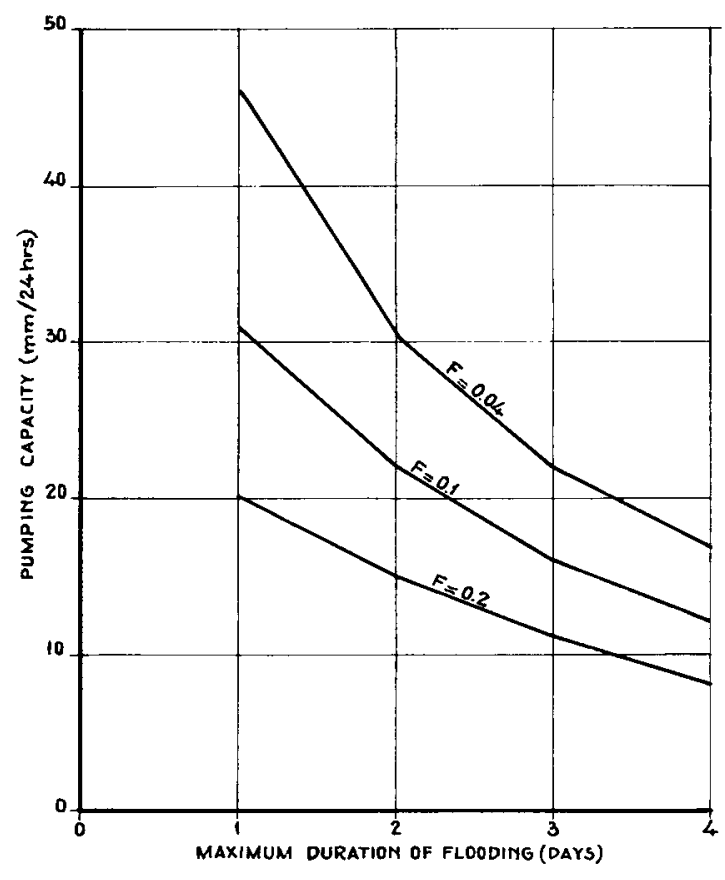

Fig. 5 Relation between pumping capacity and the duration of flooding for rains of different frequency $(F)$.

$t=5.3$ and $t=6.3$ (see Table 5). If this pumping capacity is chosen, $61-30-15=$ $16 \mathrm{~mm}$ remains in the area on top of the canal storage at the end of the first day. This causes part of the land to become flooded. If the flooding concentrates on the lowest 100 ha of the pilot farm ( $20 \%$ of the area), the average water depth will be $5 \times 1.6=$ $8 \mathrm{~cm}$.

Similar calculations can be made with a maximum duration of flooding of 3 and 4 days. The pumping capacities thus obtained are shown in Fig. 5 (the upper curve). Pumping capacities with rainfall frequencies of 0.1 and 0.2 were also calculated; they are presented by the lower lines of Fig. 5 .

Fig. 5 shows the relation between pumping capacity and the risks of flooding under the stated conditions of drain distance, without deep flow and without evapotranspiration. By varying these conditions calculations lead to the following tentative conclusions, which, however, could not be checked by field measurements:

- A drain distance of $30 \mathrm{~m}$ decreased the peak discharges somewhat, but by not more than $2 \mathrm{~mm} / 24 \mathrm{~h}$. The reason is that with larger drain distances shallow flow decreases but surface flow increases by about the same amount.

- A deep flow of $2 \mathrm{~mm} / 24 \mathrm{~h}$ reduced the peak discharges by $1-2 \mathrm{~mm} / 24 \mathrm{~h}$ for the frequencies of 0.1 and 0.2 . For a frequency of 0.04 the reduction was $2 \mathrm{~mm} / 24 \mathrm{~h}$ when flooding was allowed to last 3-4 days and $5 \mathrm{~mm} / 24 \mathrm{~h}$ when flooding lasted only 1 day.

- The rainfall events are supposed to occur in spring when the daily evapotranspiration during rainy periods is estimated to be $1 \mathrm{~mm} / 24 \mathrm{~h}$. The effect of evapotranspiration is then less than that of a deep flow of $2 \mathrm{~mm} / 24 \mathrm{~h}$. In summer, rain intensities are somewhat higher but this is annihilated by lower soil moisture contents and in- 
creased evapotranspiration so that peak discharges turned out to be lower in that season.

- The required pumping capacity can be reduced by increasing canal storage by means of a reservoir in the area. The costs of the construction of such a reservoir turned out to be considerably higher than the costs of increasing the pumping capacity. Another solution is to grow crops that are not easily damaged by flooding on the lowest-lying lands and to use these lands as storage area.

\section{References}

Beers, W. F. J. van, 1965. Some monographs for the calculatiion of drain spacings. Bull. Int. Inst. Land Reclamation Improvement (Wageningen) No 8.

Boekel, P., 1959. Evaluation of the soil structure of clay soils by means of soil consistency. Meded. LandbHogesch. OpzoekStns Staat Gent 24 (1): 363-368.

Fukuda, H., 1957. Underdrainage into ditches in soil overlying an impervious substratum. Trans. Am. Geophys. Union 38: 730-739.

Ernst, L. F., 1963. De berekening van grondwaterstroming tussen evenwijdig lopende open leidingen. Institute for Land and Water Management Research, Wageningen, the Netherlands.

Groot, J. M., 1974. Drainage investigations on heavy soils in the Upper Sava Valley, Doctor's thesis, University of Zagreb.*

Hooghoudt, S. B., 1937. Bijdragen tot de kennis van enige natuurkundige grootheden van de grond, no. 6. Versl. Landbouwk. Onderz. 43.

Hooghoudt, S. B., 1940. Bijdragen tot de kennis van enige natuurkundige grootheden van den grond, no. 7. Versl. Landbouwk. Onderz. 46.

Hoorn, J. W. van, 1960. Groundwater flow in basin clay soil and the determination of some hydrological factors in relation with the drainage system. Versl. Landbouwk. Onderz. 66.10. Pudoc, Wageningen.

Zeeuw, J. W. de \& F. Hellinga, 1958. Neerslag en afvoer. Landbouwk. Tijdschr. 70: 405-421.

\footnotetext{
* In Croatian. English translations are available at the libraries of the Institute for of Land Reclamation and Improvement (ILRI), the Institute for Land and Water Management Research (ICW), both at Wageningen, International Land Development Consultants (ILACO) and N.V. Heidemij Beheer, both at Arnhem, the Netherlands.
} 